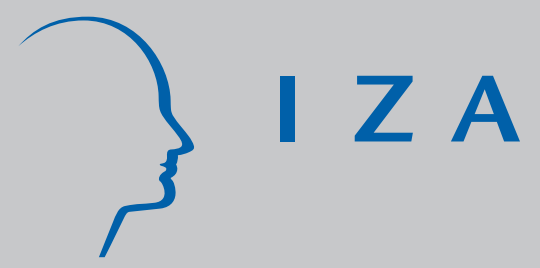

IZA DP No. 11

Employment Effects of Payroll Taxes An Empirical Test for Germany

Regina T. Riphahn

Thomas Bauer

J une 1998 


\title{
EMPLOYMENT EFFECTS OF PAYROLL TAXES \\ - AN EMPIRICAL TEST FOR GERMANY
}

\author{
Thomas Bauer \\ Regina T. Riphahn
}

Discussion Paper No. 11
June 1998

IZA

P.O. Box 7240

D-53072 Bonn

Germany

Tel: +49-228-3894-201

Fax: +49-228-3894-210

Email: iza@iza.org

This Discussion Paper is issued within the framework of IZA's research areas Mobility and Flexibility of Labor Markets and The Welfare State and Labor Markets. Any opinions expressed here are those of the author(s) and not those of the institute. Research disseminated by IZA may include views on policy, but the institute itself takes no institutional policy positions.

The Institute for the Study of Labor (IZA) in Bonn is a local and virtual international research center and a place of communication between science, politics and business. IZA is an independent, nonprofit limited liability company (Gesellschaft mit beschränkter Haftung) supported by the Deutsche Post AG. The center is associated with the University of Bonn and offers a stimulating research environment through its research networks, research support, and visitors and doctoral programs. IZA engages in (i) original and internationally competitive research in all fields of labor economics, (ii) development of policy concepts, and (iii) dissemination of research results and concepts to the interested public. The current research program deals with (1) mobility and flexibility of labor markets, (2) internationalization of labor markets and European integration, (3) the welfare state and labor markets, (4) labor markets in transition, (5) the future of work, and (6) general labor economics.

IZA Discussion Papers often represent preliminary work and are circulated to encourage discussion. Citation of such a paper should account for its provisional character.

IZA Discussion Paper No. 11 


\section{ABSTRACT}

\section{Employment Effects of Payroll Taxes - An Empirical Test for Germany*}

This study tests to what degree the incidence of payroll taxes in Germany is on employment and whether in consequence payroll taxes, in particular social insurance contributions, are the culprit behind the growing unemployment problem. Using industry level data for 18 years (1977-1994) we estimate a system of five interdependent, dynamic factor demand equations. Various simulations indicate that the employment effects of payroll taxes are minimal.

JEL Classification: J23, J32, H32

Keywords: dynamic labor demand, payroll tax, unemployment, social insurance

Regina T. Riphahn

SELAPO - Universität München

Ludwigstr. 28 RG

D - 80359 München

Germany

Tel.: +49-89-2180-2128

Fax: +49-89-336392

email: Regina.Riphahn@selapo.vwl.uni-muenchen.de

* The authors thank Don DeVoretz, Ira Gang, Dan Hamermesh, Marvin Kosters, Ralph Rotte, Christoph M. Schmidt, Viktor Steiner, and Frank Vella for helpful comments on prior versions of this paper. 


\section{Introduction}

Supported by the OECD Jobs Study (1994) it has become common knowledge that receding employment is due to high payroll taxes, and that the provisions of welfare states, which are largely financed by mandatory payroll taxes, must be cut back to facilitate a return to full employment (for the case of Germany, see SVR, 1996). Following this view, European policymakers have recently begun to reign in welfare states by relieving employers of financial obligations, tightening regulations, qualifying eligibility conditions and narrowing the targets of social policy measures (cf. Rhodes, 1996). While there may be good reasons for such reforms, a crucial element in the political argument has remained without sufficient empirical support: the effect of payroll taxes on employment. This paper examines the evidence on this issue. Afterall, a policy of driving back the welfare state to reduce nonwage labor costs can only be expected to increase labor demand if payroll taxes do have negative effects on employment.

Initial inspection of German data indeed indicates a negative relationship between payroll taxes and employment: Figure 1 shows that as the contribution rates to social insurances, i.e. payroll taxes paid by employers on gross wages, increased from 12 to 20 percent between 1960 and 1996, unemployment rates went up from less than 2 to almost 10 percent. In addition, labor costs per unit of output, a measure which controls for changes in productivity, increased strongly during the same period. On the other hand it is noteworthy that average nominal manufacturing wages net of social insurance contributions grew by 117.6 percent between 1977 and 1994. This growth rate increases by only 6 percentage points to 123.9 percent when social insurance contributions are added to nominal wages. Thus, it is not clear whether nonwage labor costs are indeed the main culprit for the lackluster employment situation in Germany. These doubts are supported by recent empirical studies for the U.S. which found the effect of payroll taxes on employment to be very small or even nil (see e.g. Gruber and Krueger, 1991, and Gruber, 1994).

We estimate a system of dynamic factor demand functions and simulate the effects of payroll taxes on manufacturing employment in Germany. This strategy allows us not only to evaluate the long-run effects on employment but also to analyse the dynamic adjustment process 
of labor demand which is generated by changing payroll taxes. We assume that contribution rates to the social insurance system are exogenous to firms' labor demand decisions. While the total effect of increasing social insurance rates on employment can only be determined in a simultaneous analysis of both sides of the labor market, the partial analysis provides an indication of the social welfare system's effects on labor demand.

Using pooled annual industry-level data, a system of five interdependent factor demand equations is estimated. In contrast to prior studies on labor demand in Germany (see e.g. König and Pohlmeier, 1988, 1989, and Hart and McGregor, 1988) we extend the set of factor inputs in the production function to include energy along with capital and labor measures. Hamermesh (1993) points out that consistent elasticity estimates can only be obtained if inputs are specified correctly. Given that energy prices more than doubled since the early 1970s (SVR, 1996) consideration of energy inputs for the manufacturing production process may be quite important. Hart and Kawasaki (1988) applied a similar estimation framework to evaluate the impact of nonwage labor costs on labor demand. However, their dataset consisted of only one aggregate time series covering the manufacturing sector for the period from 1950 through 1982 and did not include energy as an input factor. Our data is more recent and uses information on 32 industries for which we apply a fixed effects estimator with Huber-White corrected standard errors.

Our main findings are that generally factor prices have statistically significant effects on factor demands. The consideration of energy and capacity utilization as separate factors appears to be important in the study of factor demand. Contrary to the public discussion, we find that the impact of payroll taxes, such as social contribution rates, on employment is minimal. Our simulations show that shifting the tax base from employment to the capital stock may have positive employment effects over the medium term. Overall, the results indicate that reductions in social insurance rates by some percentage points will not generate significant improvements in the employment situation.

This introduction is followed by a brief description of the institutional background and of prior studies on payroll taxation. Section 3 lays out our empirical method before Section 4 
summarizes estimation and simulation results. Section 5 concludes.

\section{Background on Payroll Taxation}

\subsection{A Brief Introduction to German Institutions}

The German welfare state can be described as a set of separate but intertwined functional branches. The most important of these branches, the health, retirement and unemployment insurances, as well as (since 1995) the long term care insurance are financed through mostly mandatory contributions. The contributions are raised in approximately equal parts from employers as payroll taxes and from employees as mandatory premia based on gross earnings (for a description cf. Smith, 1994).

In 1997 total contribution rates to the social insurance schemes amounted to 41.8 percent of earnings, of which 20.05 percent were borne by employers and 21.75 by employees. ${ }^{1}$ Individuals' earnings which are subject to contributions are capped such that average contribution rates are lowest for the earners of the highest labor incomes. The earnings cap is set at about twice the average earnings. The system of individual earnings-based contributions mandatorily applies to blue and white collar wage and salary earners. Civil servants and most self-employed are not participating in the same insurances and thus are not covered by the mandatory contribution system. Beyond the contribution based social insurances, additional support mechanisms of the welfare state such as means-tested social assistance, means-tested continuation of unemployment benefits, child-support, or rent-support are funded out of general tax revenues.

The contribution rates to the separate insurance branches are periodically adjusted in order to meet funding requirements. Policy interventions have a direct impact on contribution rates e.g. through reforms of health care provisions, of retirement rules, or of active labor market

Most costly was the retirement insurance with 20.3 percent, followed by the health insurance which averages 13.3 percent of gross earnings and the unemployment insurance with 6.5 percent. The cost of the long term care insurance ( 1.7 percent) is shouldered completely by employees, while the other rates are split equally between employers and employees. 
policies. Despite numerous restrictions on expenditures for public health care, by 1997 health insurance contribution rates had increased by 58 percent or 4.9 points since 1960 (see Table 1). Due in part to more generous retirement rules retirement insurance contribution rates went up by 45 percent or 6.3 percentage points since 1960 . The contribution rates to the unemployment insurance, which also funds active labor market policies have been increasing strongly since unification, and more than tripled from a rate of 2 percent in 1960 to 6.5 percent in 1997.

\subsection{The Literature on Payroll Taxation}

Recent contributions in the literature on the incidence of payroll taxation confirm Summers' (1989) theory of a tax/benefit linkage. Prior to Summers' (1989) contribution researchers tested for employment effects of payroll taxes and found them to be negative but small (cf. Hamermesh, 1993). Summers pointed out that the employment effect might be small or even nil if workers value the additional benefit enough to accept lower wages in combination with these benefits. However, this mechanism works only if the receipt of benefits is restricted to those workers who finance it, since otherwise there is no reason to accept lower wages. In addition, it is necessary that firms can indeed reduce wages in the wake of a payroll tax hike (Gruber, 1997). This latter condition is not fulfilled in a scenario of mandatory or effective minimum wage rules.

The theory of the tax/benefit linkage was tested in a number of studies by Gruber and coauthors. They confirmed Summers' hypothesis for the U.S. where the incidence of mandated employer benefits is fully on wages with very small disemployment effects (Gruber and Krueger, 1991, Gruber 1994), and similarly for Chile (Gruber, 1997).

The shortage of comparable studies for Germany may in part be explained by the lack of drastic changes in payroll taxes (cf. Figure 1). Two additional factors limit the applicability of Summers' theory to the German case: First, the corporate bargaining system basically prevents downward adjustments in wages (cf. Machin and Manning, 1997, Dolado et al., 1996, or Schmidt, 1994). If wages cannot decline when payroll taxes go up the incidence of rising payroll taxes is likely to fall on employment. Second, the requirement of a close linkage between labor 
force participation and benefit provision is not fulfilled for the German social insurance schemes. The lack of a link is clearest in the case of health insurance: Public health insurance is financed by the contributions of the labor force and funds health care for all population groups, independent of labor force participation including family members, the unemployed, and retirees.

Since under these conditions the full incidence of payroll taxes cannot be on wages, a direct analysis of the employment effects of changes in payroll taxes is justified. We address this question within the traditional labor demand estimation framework. While studies on labor demand in Germany abound, only a few empirical investigations have looked at the impact of nonwage labor costs on labor demand and ultimately on employment in Germany. Generally, three different empirical frameworks have been applied: Structural multi-equation systems of macro models of the economy (Hansen, 1996, or Entorf et al. 1992), partial macroeconomic models (Steiner, 1996), and microeconomic systems of factor demand equations (e.g. Hart and Kawasaki, 1988).

Hansen (1996) estimates a structural macroeconomic system and simulates the effect of a permanent reduction in the nominal wage wedge by ten percent. This reduction is equivalent to a cut in employer and employee contribution rates by five percentage points and yields significant beneficial effects on output $(+6.7$ percent), employment $(+7.9$ percent $)$ and unemployment $(-2.4$ percent $)$ after a period of 14 years. The macroeconomic system modeled by Entorf et al. (1992) is used to simulate the effect of constant nonwage labor costs between 1981 and 1985. The simulations indicate that constant expenditures for nonwage labor costs between 1981 and 1985 would have reduced hours worked by 3.4 percent, increased employment by 5.1 percent over its observed level, and therefore reduced unemployment by 4.6 percentage points. Both studies indicate strong effects of nonwage labor costs on employment. These were not confirmed in papers that applied partial macromodels or which estimated systems of factor demand equations derived from models of firm behavior.

Steiner (1996) reevaluates the estimation framework that underlies the OECD jobs study (1995) and estimates a dynamic macroeconomic model of wages and employment using an error 
correction approach. He concludes that labor demand in the long run declines by 0.23 percent for every percentage point increase in employers' social insurance contribution rates. Without adjustments in indirect taxation a permanent reduction in contribution rates by three percentage points in 1980 is simulated to lead to an increase in employment by 0.62 percent after 7 years. ${ }^{2}$

Most similar to our study is the paper by Hart and Kawasaki (1988). They estimate a system of three dynamic factor demand equations on aggregate annual data jointly for the entire manufacturing industry for the period between 1950 and 1982. They distinguish separately predicted measures for wages, fixed and variable employer payroll taxes, as well as fixed and variable other nonwage labor costs. In their results employment is not significantly affected by any of the factor price measures, which might be due to the small number of only 32 observations. The wage measure has an insignificant, counterintuitively positive coefficient in the employment equation. Simulations of the effect of reductions in employers' social insurance contribution rates yield reductions in employment and capital, while the demand for hours increases. The authors conclude that a policy of reducing tax rates may encourage greater labor utilization rather than the creation of new jobs. Thus, the two latter studies agree in that the employment effects of social insurance contribution rates are small if not nil.

\section{Theoretical Model and Estimation Method}

The standard neoclassical model predicts negative own price effects on factor demand. Since payroll taxes paid by employers can be interpreted as an institutional mark-up on the price of labor, rising payroll taxes should have negative effects on the overall demand for labor. Due to substitute or complement relationships between different input factors, taxes on one factor may also affect the demand for other factors. For example, if employment and capital are substitutes, an increase in social insurance contributions paid by the employer should have negative effects on overall employment but should increase the demand for capital. On the other hand, a tax on 
capital should decrease the demand for capital and increase the demand for labor. Since we are interested not only in equilibrium factor demand for a given level of factor costs and the production relationship between the different factors but also in the adjustment process of factor demand following changes in factor prices, the estimations are performed in a dynamic instead of a static setting. ${ }^{3}$

Following the literature we assume that firms maximize discounted cash flow in a perfect capital market. All inputs are subject to adjustment costs which can be represented by a convex and quadratic function. ${ }^{4}$ Using these assumptions it can be shown that the interrelated demand for several factors can be analyzed within the following multivariate flexible accelerator model (see Nadiri and Rosen, 1973):

$$
\Delta \mathrm{Z}_{\mathrm{t}}=\mathrm{Z}_{\mathrm{t}}-\mathrm{Z}_{\mathrm{t}-1}=\Lambda\left(\mathrm{Z}^{*}-\mathrm{Z}_{\mathrm{t}-1}\right)
$$

where $\mathrm{Z}_{\mathrm{t}}$ is a vector of $\mathrm{N}$ quasi-fixed input factors and $\mathrm{Z}^{*}$ is the vector of their long-run equilibrium levels. The speed of adjustment of the input factors $Z_{t}$ to their long-run equilibrium levels $\mathrm{Z}^{*}$ is inversely proportional to their respective adjustment costs, and is decribed by the diagonal elements of the $\mathrm{NxN}$ matrix of adjustment parameters $\Lambda$. It is plausible to expect the diagonal elements of $\Lambda$ to be positive: the more current input demand deviates from the equilibrium level the larger the necessary adjustment. A stable system requires these parameters to take on values below one.

Since measures for $Z^{*}$ are not observed, equation (1) cannot be estimated directly. It is assumed that the elements of $\mathrm{Z}^{*}$ can be represented by a reduced form

$$
\mathrm{Z}_{\mathrm{t}}^{*}=\beta^{\prime} \mathrm{W}_{\mathrm{t}} \text {. }
$$

3 The theoretical and empirical literature on dynamic factor demand is surveyed by Nickell (1986), Hamermesh (1993), and Hamermesh and Pfann (1996).

Recent empirical studies suggest that linear and/or asymmetric adjustment costs are a better aproximation to the observed adjustment patterns of factor demand (a recent example for Germany is given by Kraft, 1997, an overview of this literature is given by Hamermesh and Pfann, 1996). However, due to data limitations and for the sake of simplicity we follow the bulk of the literature on dynamic factor demand by assuming convex and symmetric adjustment costs. 
where vector $\mathrm{W}$ combines the determinants of the equilibrium demand for the elements of $\mathrm{Z}^{*}$ which include factor prices and determinants of the demand for final output, such as exports or past output. Since these determinants are endogenous to final factor demand, predicted values are used in the estimation. Each element of vector $\mathrm{W}$ is predicted based on its lagged values, a time trend $(\mathrm{t})$ and its square $\left(\mathrm{t}^{2}\right)$, with $\eta_{\mathrm{t}}$ representing a normally distributed error term with mean zero and variance $\sigma_{\eta}^{2}$ :

$$
\mathrm{W}_{\mathrm{t}}=\gamma_{0}+\gamma_{1} \mathrm{~W}_{\mathrm{t}-1}+\gamma_{2} \mathrm{~W}_{\mathrm{t}-2}+\gamma_{3} \mathrm{t}+\gamma_{4} \mathrm{t}^{2}+\eta_{\mathrm{t}}
$$

This procedure follows Rossana (1990) and Hart and Kawasaki (1988) who use univariate timeseries methods and regressions on lagged endogenous and exogenous measures respectively to predict the endogenous variables. Having predicted $W_{t}, Z^{*}$ enters equation (1) as a linear combination of its predicted determinants

$$
\hat{\mathrm{Z}}_{\mathrm{t}}^{*}=\beta^{\prime} \hat{\mathrm{W}}_{\mathrm{t}}
$$

Employment, hours, capital stock, capacity utilization, and energy are considered as inputs in the production function of the manufacturing sector. Existing labor demand studies for Germany (see e.g. Nakamura, 1986, König and Pohlmeier, 1988, Flaig and Steiner, 1989, or FitzRoy and Funke, 1994) did not consider energy and capacity utilization as separate factors. Prior studies (Artus and Peyroux, 1990, or Keane and Prasad, 1996) have shown that firms make joint decisions on the demand for energy and other inputs, and that the demand for energy affects the relative prices of other factors across industries. Given that the omission of a relevant factor biases the estimated demand coefficients and given the large factor adjustments that were prompted by energy price shocks after 1973 (see Figure 1), the consideration of energy as a separate factor appears indispensable. We consider gross wages, the user cost of capital as well as the price of energy as the relevant factor prices. Assuming that labor demand responds to gross factor costs we do not distinguish explicitly between the effects of wage and non-wage 
labor costs such as social insurance contribution rates in the estimation. ${ }^{5}$ As noted above, $\hat{Z}_{\mathrm{t}}{ }^{*}$ further includes the output level, measured as the effective volume of gross value added in the industry, and the share of exports out of total revenues to control for determinants of factor demand other than factor prices.

Taking logarithms of all variables and substituting equation (4) into (1), the final estimation equation for each of the five inputs $(i, j=1, \ldots, 5)$ takes on the following form:

$$
\ln \mathrm{Z}_{\mathrm{i}, \mathrm{t}}-\ln \mathrm{Z}_{\mathrm{i}, \mathrm{t}-1}=\alpha_{\mathrm{i}, 0}+\sum_{\mathrm{j}=1}^{4} \alpha_{\mathrm{i}, \mathrm{j}, 1} \ln \mathrm{Z}_{\mathrm{j}, \mathrm{t}-1}+\alpha_{\mathrm{i}, 2} \ln \hat{\mathrm{W}}_{\mathrm{t}}+m \mathrm{y}_{\mathrm{i}, \mathrm{t}}
$$

$\alpha_{\mathrm{i}, 0}$ represents the constant term, $\alpha_{\mathrm{i}, \mathrm{j}, 1}$ and $\alpha_{\mathrm{i}, 2}$ are slope coefficients. Of special interest are first the coefficients $\alpha_{\mathrm{i}, \mathrm{i}, 1}$, which measure the speed and with it the cost of own adjustment as $\alpha_{\mathrm{i}, \mathrm{i}, 1}=-\lambda_{\mathrm{i}, \mathrm{i}}$, and, second, the coefficients of the predicted factor prices in $\alpha_{\mathrm{i}, 2}$. The closer $\alpha_{i, i, 1}$ gets to a value of one the faster is the adjustment of a factor towards its equilibrium value implying low adjustment costs. The coefficients $\alpha_{i, j, 1}$ for $\mathrm{i} \neq \mathrm{j}$ indicate whether two factors $\mathrm{i}$ and $\mathrm{j}$ are dynamic substitutes or complements, i.e. whether a disequilibrium in the demand for factor $\mathrm{j}$ speeds up $\left(\alpha_{\mathrm{i}, \mathrm{j}, 1}<0\right)$ or slows down $\left(\alpha_{\mathrm{i}, \mathrm{j}, 1}>0\right)$ the adjustment process for factor $\mathrm{i}$ (Hamermesh, 1993).

\section{Estimation and Simulation Results}

The estimations were performed using annual data on 32 manufacturing industries for the period between 1977 and $1994 .^{6}$ This dataset is more disaggregated than those used in existing empirical studies on dynamic factor demand in Germany (see Hamermesh, 1993, for an overview). Over time and across industries the wage and employment developments show

Available data do not allow to differentiate between contract and overtime hours. Given wage premiums on overtime work, this may introduce measurement error into the wage variable.

6 Since industry classifications where modified in 1995 to adhere to European standards, data after 1994 could not be used. Ideally one would consider service sector industries as well, however, sufficiently detailed data are not available. 
considerable variation. The changes in employment over the observation period (1977 through 1994) range from 2.28 percent for the plastics industry to -5.07 percent for leather production. Changes in wages vary between 7.17 percent for the tobacco industry and 4.95 percent for the iron industry. In addition, for any given industry wages varied significantly over time, with an average standard deviation of the annual growth rates of 2.45. Details on variable definitions, data sources, and descriptive statistics are given in the Appendix. In this section we first present the estimation results of the dynamic factor demand equations described above. Based on these results several simulation experiments were performed which shed light on the relevance of taxes for the development of labor demand and employment.

\subsection{Estimation Results}

Since we use pooled time-series data we tested for autocorrelation in the error terms. In the presence of lagged endogenous variables the traditional Durbin-Watson test is not applicable. Therefore, we estimated equations (5) separately for each industry and input factor $(5 * 32$ estimations), retained the error terms, and performed Box-Pierce and Box-Ljung tests for autocorrelation of first and second order. At the 95 percent confidence level we could not reject the absence of first order autocorrelation in 26 out of 160 cases by the Box-Pierce statistic and in 35 cases when applying the Box-Ljung test. According to the Box-Pierce (Box-Ljung) statistic only in 23 (35) out of 160 cases second order autocorrelation could not be rejected. Since these results suggest that autocorrelation appears only in a few cases we decided to ignore it.

Table 2 presents estimation results of equations (5) with robust Huber-White corrected standard errors in order to control for heteroskedastic standard errors. ${ }^{7}$ To control for unobserved industry-specific heterogeneity such as the level of market concentration, union power, or technology, which may be correlated with the determinants of factor demand, we apply a fixed effects estimator.

As required by theory all own-adjustment parameters are significantly negative and

$7 \quad$ See Huber (1964) and White (1980) for the method of calculating these standard errors. 
smaller than one, indicating that a firm will reduce the level of an input factor if it has more of that input than it desires (remember from equation (1) and (5) that we estimate $-\Lambda$ ). The ownadjustment coefficients of employment and capital are close to zero indicating a slow adjustment to a new equilibrium level and high adjustment costs. Energy adjusts slightly faster to a new equilibrium level. Compared to the stock measures of labor and capital the coefficients of the utilization variables, i.e. hours and capacity utilization, display rapid own-adjustment, similar to energy. These results confirm other empirical studies in this area (see e.g. Rossana, 1990) and are consistent with the expectation that the adjustment of stocks is more costly than the adjustment of utilization rates. The own-adjustment coefficients for employment, hours and capital are quite similar to those obtained by Hart and Kawasaki (1988). ${ }^{8}$

Table 2 shows that hours have a statistically significant positive impact on employment which suggests that firms will increase employment if hours per worker are above the equilibrium value. On the other hand, the statistically significant negative effect of employment in the hours equation indicates that employment is a substitute for hours. Together with the estimated differences in the speed of own adjustment, these results suggest that firms react to a positive (negative) shift to labor demand by first raising (reducing) hours. When the positive (negative) labor demand shift is sustained, they further react by increasing (decreasing) employment. These results are in line with most of the empirical studies on interrelated factor demand (see Hamermesh, 1993, Table 7.4, for a survey). A similar though weaker pattern is found for the stock and utilization variables for capital, since capacity utilization is a statistically significant complement to capital whereas the latter has a negative but statistically insignificant effect on the change of capacity utilization.

Concerning the cross-adjustment parameters we find no significant influence of capital in the two labor demand equations. Capacity utilization has a significantly positive effect on employment and a significantly negative effect on hours. The capital measures are significantly

$8 \quad$ Hart and Kawasaki (1988) estimated equation (5) in levels rather than in differences. Therefore, their own-adjustment coefficients, which are 0.928 for employment, of 0.369 for hours, and of 0.914 for capital stock, must be substracted from 1 to be comparable to our estimates. 
affected only by employment which is a complement to the stock of capital and a substitute to capacity utilization. Once again, these results are similar to those of Hart and Kawasaki (1988). The cross-adjustment parameters between energy and hours reveal that these two inputs are substitutes, but only in the hours equation at a statistically significant level. No significant relationship was found between energy and employment, and energy and capital.

In accordance with theoretical expectations, most factor inputs are inversely related to their own factor price. Only between employment and wages a positive but statistically insignificant relationship appears, whereas a statistically significant negative relationship between wages and hours could be revealed. Similar studies often found wages to be statistically irrelevant for employment demand (see Rossana, 1990, and Hart and Kawasaki, 1988). The capital stock and capacity utilization are negatively related to predicted interest rates but only for the capital stock at a significant level. The coefficient of the user cost of capital is smaller than that found by Hart and Kawasaki (1988) and König and Pohlmeier (1988), which can be explained in part by the different scaling: Their user cost is measured in percent $(\%)$, the one used here is measured in "permille" (\%o). Compared to the own price effects on hours and capital, the estimations reveal a high response of energy demand to its price. The cross-price effects of the user cost of capital are negative with respect to employment and positive for the utilization of labor. Interestingly, no significant direct effect of the energy price on the measures of labor inputs is found. Based on the experience of the oil price crises one might have expected a negative relationship. Furthermore, capacity utilization is not affected by input prices. Finally, total output and export shares are positively related to all input demands, which appears plausible.

The last five rows of Table 2 report long run elasticities which have been computed from the stationary solutions of equations (5). The long-run wage elasticity of employment is estimated to be -0.52 , which is at the upper bound of the elasticities found in previous studies for 
Germany. ${ }^{9}$ The calculated elasticity between wages and hours per worker of -0.13 is slightly lower than that found by König and Pohlmeier (1988). Based on contribution rates as of 1996 (20\%) the estimated long-run elasticities for the two labor inputs imply a payroll tax elasticity of employment and hours amounting to -0.09 and -0.02 , respectively, which is quite small. The negative user cost of capital elasticity of employment is unexpected. However, it seems that this negative elasticity is dominated by the comparably high positive elasticity between capital user costs and hours per worker. Concerning the other long run elasticities it should be noted that all own-price elasticities have the expected negative sign. The elasticities of employment, capital and energy with regard to output and exports are positive and have plausible values, while the small negative elasticities between output, exports, hours per worker, and capacity utilization are counterintuitive. $^{10}$

\subsection{Simulation Results}

The estimation results described so far do not provide a clear indication of the employment effects of payroll taxes: The estimated factor demand equations are interrelated, thus changes in a given factor price affect factor demand directly and indirectly through lagged effects. The long run elasticities solve this problem but do not bear any indication of the short-run adjustment effects which are of interest here. Also, we have not quantified the relative impact of changes in wages and non-wage labor costs.

To evaluate the effect of payroll taxes on employment we apply simulation methods. The first step in our simulation procedure is to predict factor demands as of 1977 using the first observed values of the explanatory variables (1977) in combination with the estimated

Franz and König (1986) find the wage elasticity of employment to be -0.53 . Estimating an errorcorrection model of employment Flaig and Steiner (1989) obtain a long-run elasticity of -0.13. Using data on German manufacturing König and Pohlmeier (1988) find an elasticity of -0.18 and FitzRoy and Funke (1994) obtain estimates which range between -0.15 and -0.33 . Estimating separate employment equations for 27 industries, Stark and Jänsch (1988) find elasticities which are overwhelmingly greater than -0.5. The results of Stark and Jänsch are confirmed by Kraft (1991) using data on 24 industries. 
coefficients. These predicted factor demands are then - together with the observed values of the other variables - utilized as lagged values in the prediction equations for the factor demands as of 1978. By the same procedure the factor demands of subsequent years are generated. In a first simulation experiment we predicted factor demands under three scenarios for the development of the contribution rates through time (for a description of how contribution rates affect the wage variable, see the Appendix). In the first scenario the contribution rates were left constant at their 1977 values (16.2 percent), in the second scenario we assumed that contribution rates took on the constant value of 18 percent, and in the third scenario contribution rates were set to a value of 20 percent for the entire period of observation. Panel A of Table 3 and Figure 2 describe the simulated paths of factor demands.

We find a negative impact of social insurance contribution rates on the development of employment and hours worked. However, Table 3(A) reveals that the size of the simulated effects is negligible. A comparison of the second and third scenario shows that an increase of the contribution rates by 2 percentage points in 1977 induces a reduction in employment after 18 years by about 0.8 percent, a reduction in the hours worked by about 0.2 percent, and has basically no effects on the demands for capital, energy, and capacity utilization. A simulation based "social insurance rate elasticity of employment demand" is thus quite small at -0.073 and close to the estimation based long-run elasticity reported above. Table 3(A) also shows, that the increase in contribution rates slightly reduces capacity utilization before returning to the level it would have reached without an increase in the contribution rates.

These findings confirm the results of Steiner (1996), and Hart and Kawasaki (1988), and are in contrast to the large employment effects of Hansen (1996) or Entorf et al. (1992). For the four year period 1981 through 1985 Entorf et al. (1992) simulated a 5.1 percent increase in employment when nonwage labor costs remained constant. Relative to the predicted value of 7.07 million manufacturing employees in 1985 in a scenario where contribution rates remain at their observed values, we find only a 0.1 percent increase in employment by 1985 if social insurance contribution rates had stayed constant at their 1977 level of 16.2 percent. Possible 
explanations for the divergent results might lie in the different estimation approaches, and more importantly in the simulated effects themselves: While this study focuses on social insurance contributions, Entorf et al. (1992) as well as Hansen (1996) phrase their problems more generally in terms of a wage wedge, or nonwage labor costs. If nonwage labor costs other than social insurance contributions ${ }^{11}$ largely increased in the considered period the difference in results might be explainable.

In a next step we generated a measure for the relative sensitivity of factor demands to price changes by simulating the effects of imposing taxes on alternative factors and prices. Panel B of Table 3 and Figure 3 describe the effects of a 15 percent tax on wages, on the user costs of capital, and on energy prices, always assuming that there is no tax on the respective other prices. Replacing a payroll tax of $15 \%$ by a tax on the user cost of capital or on the price of energy results in increased employment and more hours per worker. Table 3(B) shows that, compared to a payroll tax, employment in 1994 would be $6.4 \%$ (6.5\%) and hours per hours per worker $3.5 \%(2.2 \%)$ higher, if the tax on wages were replaced by a tax on the user cost of capital (energy price). While at first a 6.5 percent increase in employment may appear sizeable, as the cumulative effect of 18 years without any social insurance contributions it is not large. Figure 3 and Table 3(B) also show that the demand for capital and capacity utilization would decrease, if the user cost of capital or the energy price were taxed instead of wages. Compared to the situation of a payroll tax the use of energy would decrease in case of an energy tax and increase if user costs of capital were the tax base. Overall, these results indicate that lowering payroll taxes and increasing the taxation of capital or energy may result in higher employment. A comparison of the response rates of factor demands to changes in their own prices roughly confirms the long-run elasticities discussed above: While the demands for employment, capital and energy respond relatively clearly to changes in their factor prices, the sensitivity of utilization measures such as hours per week and capacity utilitzation is small.

Shifting from a 15 percent payroll tax to a 15 percent tax on energy leads to drastically 
reduced revenues. Since the last experiment ignored revenue consequences of shifting tax bases, Panel $\mathrm{C}$ in Table 3 and Figure 4 present the results of a final simulation experiment where we calculated the effects of raising the 1994 payroll tax revenue by taxing different input factors. Since energy expenditures are too small a tax base to yield a comparable revenue and because it is not realistic to levy a tax on the user cost of capital, a constant 19.55 percent contribution rate on labor costs is compared to a 5.67 percent tax rate on the stock of capital which would have yielded the same revenue in 1994. Figure 4 shows that shifting the tax burden from wages to the capital stock induces an increase in the demand for labor, hours per worker, and energy, whereas the demand for capital decreases only slightly. Table 3(C) shows that in 1994 employment would have been $9.5 \%$, hours per worker $2.3 \%$, and the use of energy $2.7 \%$ higher if the revenues based on the contribution rates would have been raised by a tax on the capital stock instead of payroll taxes. Interestingly, this procedure will also induce a slight increase of $0.2 \%$ in the demand for capital. An explanation for this result could be that the negative demand effects of taxing capital are compensated by the positive effects which result from higher employment. Finally, replacing contribution rates by a tax on capital will result in a slightly reduced capacity utilization.

\section{Conclusion}

Following OECD recommendations policy makers and public opinion appear to have come to a consensus on the cause of the dismal unemployment situation in Europe: high payroll taxes. This study evaluates the empirical evidence for the suggested employment effects of payroll taxes using industry level data from Germany.

The empirical model considers five dynamic, interrelated factor demand equations for manufacturing industries which allow us to determine the long-run wage elasticity of labor demand and to simulate the short-run effects of changes in payroll taxation. We find that stock measures of factor demand such as the number of employees and the capital stock respond stronger to changes in factor costs than utilization measures such as hours worked and the 
capacity utilization rate. We simulate the paths labor demand would have taken under different scenarios of payroll tax developments and find that employment is not sensitive to this component of the wage bill. Ceteris paribus an increase in the social insurance contribution rate by two percentage points in 1977 would have reduced employment by 0.8 percent after 18 years. This finding agrees with studies using similar methods to evaluate the effects of nonwage labor costs, and raises doubts as to whether the public debate has identifeed the most appropriate policy tool to fight unemployment. Even if contributions to social insurances were abolished completely and revenues were raised based on the taxation of the capital stock - an unlikely scenario - the employment effects after 18 years would not exceed a 9.5 percent employment increase.

Our intention is not to add to the literature on the choice of an appropriate tax base (for studies on these issues see e.g. Elixmann et al., 1985, Peeters, 1986, Bußmann et al., 1992) nor to argue for a replacement of payroll taxes by any type of "machine tax." Instead it is our objective to draw attention to the finding that the impact of payroll taxes on employment demand in Germany is actually quite limited. Therefore the solution to the unemployment problem cannot be found in a reduction of the contribution rates by some percentage points and by a corresponding reduction in social insurance provisions. Instead the perspective needs to be broadened to include a wider range of policy instruments. Possible candidates include other nonwage labor costs, and restrictive labor market regulations affecting wage setting, hiring and firing. As long as the unemployment discussion remains focused on some percentage points in the social insurance contribution rates it is "barking up the wrong tree." 
Table 1: Development of Social Insurance Contribution Rates

\begin{tabular}{lccc|}
\hline Insurance Type & 1960 Rate & 1997 Rate & Increase in Percent \\
\hline Health Insurance & 8.4 & 13.3 & 58 \\
Retirement Insurance & 14.0 & 20.3 & 45 \\
Unemployment Insurance & 2.0 & 6.5 & 225 \\
Long Term Care Insurance & - & 1.7 & - \\
Total & $\mathbf{2 4 . 4}$ & $\mathbf{4 1 . 8}$ & $\mathbf{7 1}$ \\
\hline
\end{tabular}


Table 2: $\quad$ Estimation Results

Endogenous Variable

\begin{tabular}{|c|c|c|c|c|c|}
\hline Exogenous Variable & $\Delta$ Employment & $\Delta$ Hours & $\Delta$ Capital & $\Delta$ Capacity Utilization & $\Delta$ Energy \\
\hline Employment $_{t-1}$ & $\begin{array}{c}-0.085^{\dagger \dagger} \\
(0.038)\end{array}$ & $\begin{array}{c}-0.043^{\dagger} \\
(0.015)\end{array}$ & $\begin{array}{l}0.042^{\dagger \dagger} \\
(0.016)\end{array}$ & $\begin{array}{c}-0.107^{\dagger \dagger} \\
(0.044)\end{array}$ & $\begin{array}{l}-0.045 \\
(0.058)\end{array}$ \\
\hline Hours $_{t-1}$ & $\begin{array}{l}0.458^{\dagger \dagger} \\
(0.139)\end{array}$ & $\begin{array}{c}-0.518^{\dagger \dagger} \\
(0.053)\end{array}$ & $\begin{array}{c}0.067 \\
(0.048)\end{array}$ & $\begin{array}{c}0.073 \\
(0.118)\end{array}$ & $\begin{array}{l}-0.045 \\
(0.144)\end{array}$ \\
\hline Capital $_{t-1}$ & $\begin{array}{l}-0.047 \\
(0.032)\end{array}$ & $\begin{array}{l}-0.003 \\
(0.013)\end{array}$ & $\begin{array}{l}-0.065^{\dagger \dagger} \\
(0.017)\end{array}$ & $\begin{array}{l}-0.020 \\
(0.036)\end{array}$ & $\begin{array}{l}-0.009 \\
(0.041)\end{array}$ \\
\hline Capacity Utilization $\mathrm{t}_{\mathrm{t}-1}$ & $\begin{array}{l}0.127^{\dagger \dagger} \\
(0.051)\end{array}$ & $\begin{array}{c}-0.056^{\dagger \dagger} \\
(0.017)\end{array}$ & $\begin{array}{c}0.046^{\dagger} \\
(0.024)\end{array}$ & $\begin{array}{c}-0.408^{\dagger \dagger} \\
(0.027)\end{array}$ & $\begin{array}{l}-0.030 \\
(0.068)\end{array}$ \\
\hline Energy $_{t-1}$ & $\begin{array}{c}0.009 \\
(0.037)\end{array}$ & $\begin{array}{c}-0.034 \\
(0.015)\end{array}$ & $\begin{array}{c}0.013 \\
(0.010)\end{array}$ & $\begin{array}{l}-0.036 \\
(0.042)\end{array}$ & $\begin{array}{c}-0.277^{\dagger \dagger} \\
(0.084)\end{array}$ \\
\hline Pred. Wages & $\begin{array}{c}0.009 \\
(0.038)\end{array}$ & $\begin{array}{l}-0.094^{\dagger \dagger} \\
(0.013)\end{array}$ & $\begin{array}{c}0.026 \\
(0.017)\end{array}$ & $\begin{array}{l}-0.041 \\
(0.042)\end{array}$ & $\begin{array}{l}-0.074 \\
(0.056)\end{array}$ \\
\hline Pred. Interest Rates & $\begin{array}{l}-0.074^{\dagger \dagger} \\
(0.037)\end{array}$ & $\begin{array}{l}0.064^{\dagger \dagger} \\
(0.020)\end{array}$ & $\begin{array}{l}-0.035^{\dagger \dagger} \\
(0.017)\end{array}$ & $\begin{array}{l}-0.010 \\
(0.047)\end{array}$ & $\begin{array}{c}0.049 \\
(0.067)\end{array}$ \\
\hline Pred. Energy Price & $\begin{array}{l}-0.014 \\
(0.023)\end{array}$ & $\begin{array}{l}-0.005 \\
(0.008)\end{array}$ & $\begin{array}{l}-0.009^{\dagger} \\
(0.005)\end{array}$ & $\begin{array}{l}-0.041 \\
(0.043)\end{array}$ & $\begin{array}{l}-0.117^{\dagger \dagger} \\
(0.036)\end{array}$ \\
\hline Pred. Output Level & $\begin{array}{l}0.079^{\dagger \dagger} \\
(0.029)\end{array}$ & $\begin{array}{l}0.052^{\dagger \dagger} \\
(0.010)\end{array}$ & $\begin{array}{c}0.021^{\dagger} \\
(0.012)\end{array}$ & $\begin{array}{c}0.100^{\dagger} \\
(0.060)\end{array}$ & $\begin{array}{l}0.258^{\dagger \dagger} \\
(0.043)\end{array}$ \\
\hline Pred. Export Share & $\begin{array}{l}0.062^{\dagger \dagger} \\
(0.029)\end{array}$ & $\begin{array}{c}0.008 \\
(0.006)\end{array}$ & $\begin{array}{c}0.018^{\dagger} \\
(0.010)\end{array}$ & $\begin{array}{c}0.038 \\
(0.030)\end{array}$ & $\begin{array}{l}0.099^{\dagger \dagger} \\
(0.039)\end{array}$ \\
\hline Constant & $\begin{array}{l}-1.730^{\dagger \dagger} \\
(0.514)\end{array}$ & $\begin{array}{l}2.181^{\dagger \dagger} \\
(0.259)\end{array}$ & $\begin{array}{c}-0.408^{\dagger \dagger} \\
(0.154)\end{array}$ & $\begin{array}{l}2.041^{\dagger \dagger} \\
(0.512)\end{array}$ & $\begin{array}{c}0.547 \\
(0.530)\end{array}$ \\
\hline Adjusted $\mathrm{R}^{2}$ & 0.44 & 0.37 & 0.84 & 0.17 & 0.27 \\
\hline \multicolumn{6}{|c|}{ Long-run Factor Demand Elasticities } \\
\hline Pred. Wages & -0.515 & -0.130 & -0.085 & 0.028 & -0.161 \\
\hline Pred. Interest Rates & -0.010 & 0.116 & -0.385 & 0.010 & 0.173 \\
\hline Pred. Energy Price & -0.014 & 0.025 & -0.239 & -0.045 & -0.412 \\
\hline Pred. Output Level & 0.531 & -0.024 & 0.829 & -0.066 & 0.818 \\
\hline Pred. Export Share & 0.291 & -0.027 & 0.478 & -0.037 & 0.302 \\
\hline
\end{tabular}

Notes: 1. All equations include 31 industry dummies.

2. Except for industry dummies all variables are in logarithms.

3. Huber standard errors in parentheses.

4. A $\dagger \dagger$ indicates significance at least at the 5\%-level, a $\dagger$ at least at the $10 \%$ level.

5. All equations are estimated based on $\mathrm{N}=576$ observations.

6. Long-run elasticities are calculated using the stationary solution to the system of equations in (5) (cf. Nadiri and Rosen, 1969). 
Table 3: $\quad$ Simulation Results

\begin{tabular}{|c|c|c|c|c|c|c|c|c|c|}
\hline & \multirow[t]{2}{*}{$\begin{array}{l}\text { Observed } \\
\text { Values }\end{array}$} & \multicolumn{3}{|c|}{$\begin{array}{l}\text { A: Variation in } \\
\text { Payroll Tax }\end{array}$} & \multicolumn{3}{|c|}{$\begin{array}{c}\text { B: } 15 \% \text { Tax on } \\
\text { Factor Prices }\end{array}$} & \multicolumn{2}{|c|}{$\begin{array}{c}\text { C: Revenue } \\
\text { Neutral Taxes }\end{array}$} \\
\hline & & $16.2 \%$ & $18 \%$ & $20 \%$ & Labor & Capital & Energy & Labor & Capital \\
\hline \multicolumn{10}{|c|}{ Employment } \\
\hline 1980 & 7478 & 7597 & 7586 & 7575 & 7604 & 7569 & 7644 & 7577 & 7704 \\
\hline 1985 & 6797 & 7073 & 7034 & 6992 & 7100 & 7348 & 7373 & 7001 & 7467 \\
\hline 1990 & 7238 & 6735 & 6686 & 6633 & 6769 & 7145 & 7157 & 6645 & 7233 \\
\hline 1994 & 6231 & 6440 & 6389 & 6335 & 6474 & 6886 & 6895 & 6348 & 6953 \\
\hline \multicolumn{10}{|c|}{ Hours } \\
\hline 1980 & 1053 & 1062 & 1060 & 1057 & 1064 & 1104 & 1088 & 1058 & 1087 \\
\hline 1985 & 1031 & 1030 & 1028 & 1026 & 1032 & 1070 & 1056 & 1026 & 1052 \\
\hline 1990 & 992 & 1005 & 1003 & 1001 & 1006 & 1042 & 1029 & 1001 & 1025 \\
\hline 1994 & 965 & 972 & 970 & 968 & 974 & 1008 & 995 & 969 & 991 \\
\hline \multicolumn{10}{|c|}{ Capital } \\
\hline 1980 & 981 & 966 & 966 & 967 & 965 & 946 & 954 & 967 & 958 \\
\hline 1985 & 1040 & 1041 & 1042 & 1042 & 1041 & 1007 & 1020 & 1042 & 1035 \\
\hline 1990 & 1163 & 1126 & 1127 & 1127 & 1126 & 1085 & 1101 & 1127 & 1125 \\
\hline 1994 & 1242 & 1216 & 1216 & 1216 & 1216 & 1169 & 1189 & 1216 & 1218 \\
\hline \multicolumn{10}{|c|}{ Energy } \\
\hline 1980 & 155 & 152 & 151 & 151 & 152 & 158 & 150 & 151 & 155 \\
\hline 1985 & 163 & 154 & 153 & 153 & 154 & 162 & 150 & 153 & 158 \\
\hline 1990 & 181 & 173 & 172 & 172 & 173 & 182 & 168 & 172 & 177 \\
\hline 1994 & 176 & 183 & 182 & 182 & 183 & 192 & 177 & 182 & 187 \\
\hline \multicolumn{10}{|c|}{ Capacity Utilization } \\
\hline 1980 & 2734 & 2678 & 2674 & 2670 & 2680 & 2714 & 2688 & 2671 & 2713 \\
\hline 1985 & 2685 & 2643 & 2641 & 2639 & 2644 & 2669 & 2645 & 2639 & 2661 \\
\hline 1990 & 2885 & 2726 & 2726 & 2726 & 2726 & 2733 & 2713 & 2726 & 2726 \\
\hline 1994 & 2615 & 2727 & 2728 & 2728 & 2726 & 2725 & 2706 & 2728 & 2719 \\
\hline
\end{tabular}

Note:

All figures are sums of the factor input measures across the 32 industries. 
Figure 1: Unemployment and Social Insurance Contribution Rate (1960 - 1995)

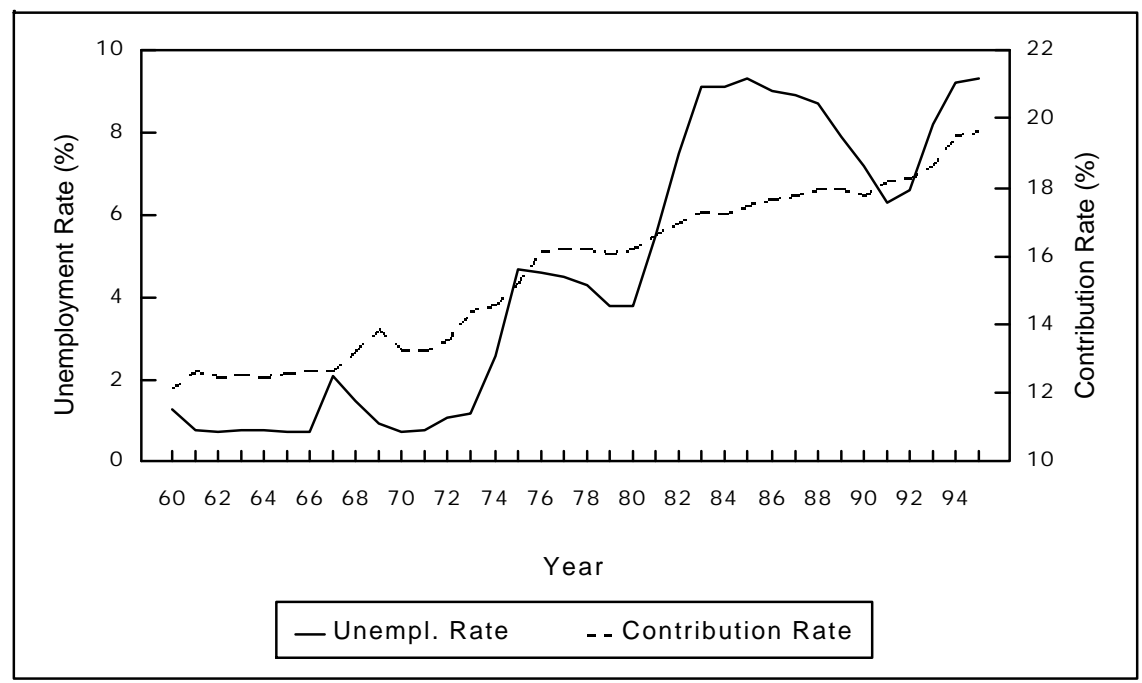

Source:

Bundesminister für Arbeit und Sozialordnung (1990) and VDR (1994). All figures are for West Germany. 
Figure 2: $\quad$ Labor Demand Effects of Different Social Insurance Contribution Rates
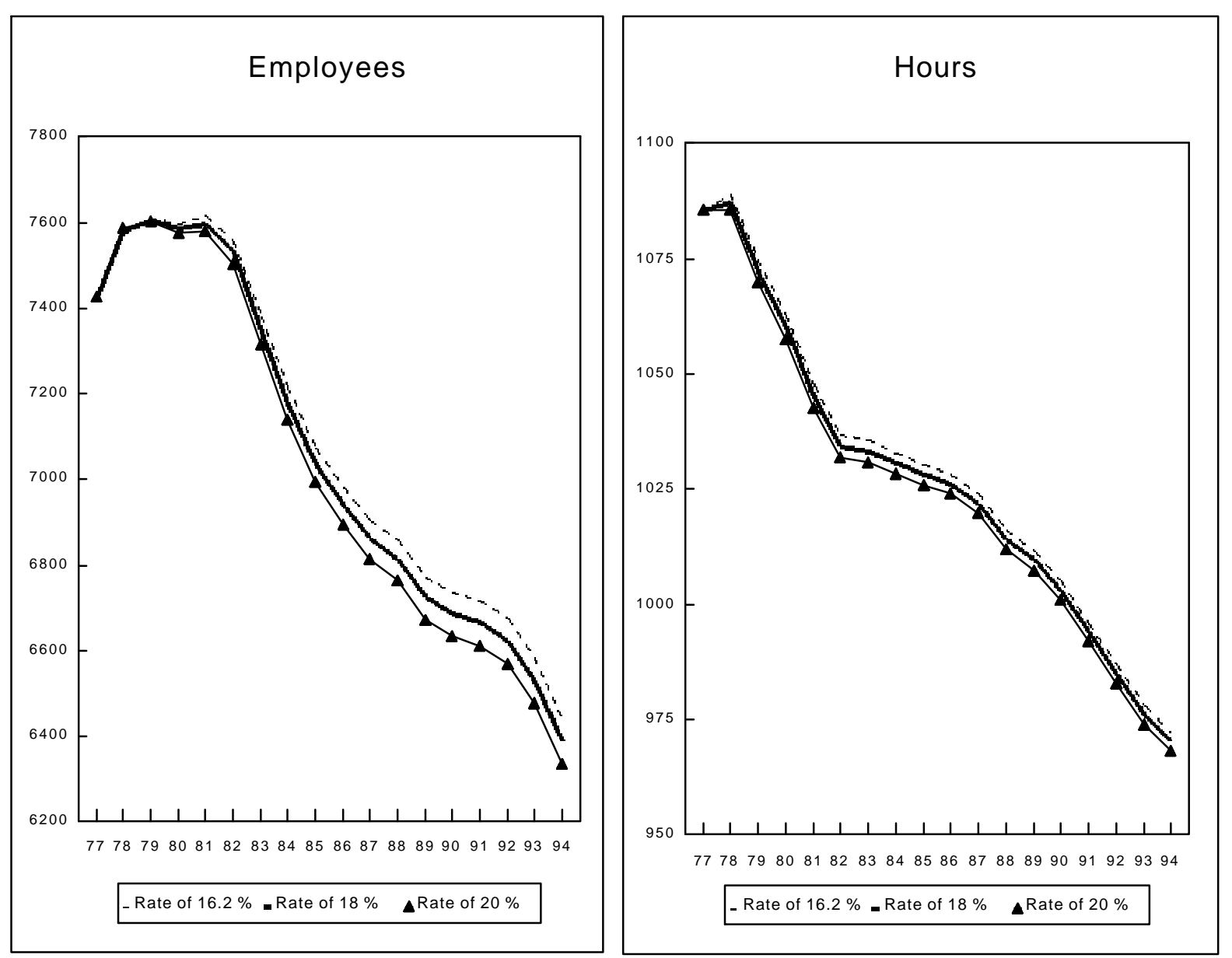
Figure 3: $\quad$ Factor Demand Effects of Taxing Alternative Factor Prices
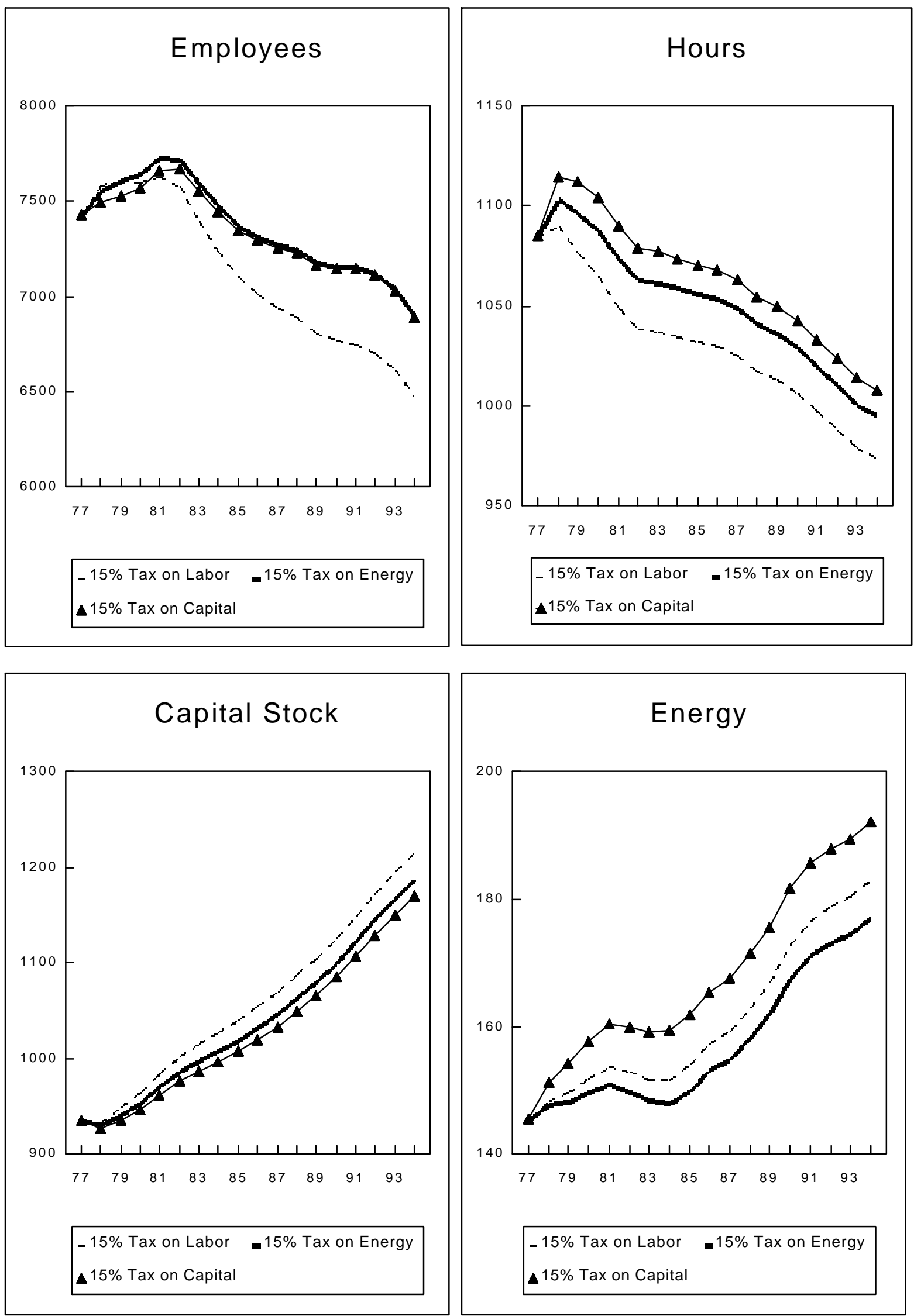
Figure 4: Factor Demand Effects of Alternative Funding Sources for Social Incurances
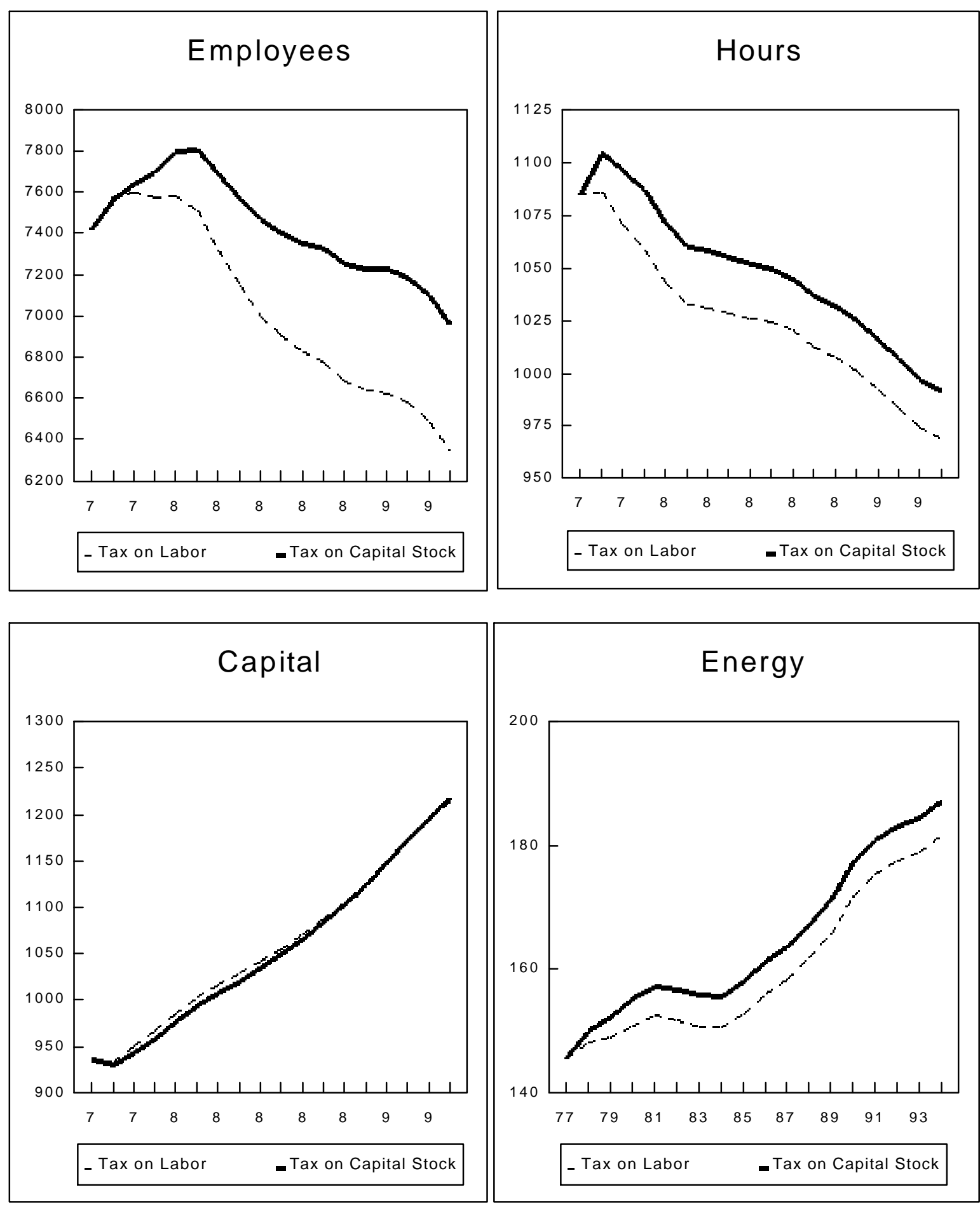


\section{References}

Artus, Patrick, and Claude Peyroux, 1990, Production Functions with the Energy Factor: Estimations for the Major OECD Countries, in: Artus, Patrick and Pierre-Alain Muet, Investment and Factor Demand, Contributions to Economic Analysis no. 193, North Holland, 175-209.

Bußmann, Ludwig, Walter A.S. Koch, and Perygrin Warneke, 1992, Der Wertschöpfungsbeitrag zur Finanzierung der Gesetzlichen Rentenversicherung, Campus Verlag, Frankfurt/New York.

Dolado, Juan, Francis Kramarz, Stephen Machin, Alan Manning, David Margolis, and Coen Teulings, 1996, The Economic Impact of Minimum Wages in Europe, Economic Policy 23, 317-372.

Elixmann, Dieter, Harald Joerg, Hubert Kreuer, and Hermann T. Sarrazin, 1985, Der "Maschinenbeitrag" - Gesamtwirtschaftliche Auswirkungen alternativer Bemessungsgrundlagen für die Arbeitgeberbeiträge zur Sozialversicherung, J.C.B. Mohr (Paul Siebeck), Tübingen.

Entorf, Horst, Heinz König, and Winfried Pohlmeier, 1992, Labor, Utilization and Nonwage Labor Costs in a Disequilibrium Macro Framework, Scandinavian Journal of Economics 51, 71-83.

FitzRoy, Felix, and Michael Funke, 1994, Real Wages, Investment and Employment: New Evidence from West German Sectoral Data, Weltwirtschaftliches Archiv 130, 258-272.

Flaig, Gebhard, and Viktor Steiner, 1989, Stability and Dynamic Properties of Labour Demand in West-German Manufacturing, Oxford Bulletin of Economics and Statistics 51, 395-412.

Franz, Wolfgang, 1991, Arbeitsökonomik, Berlin.

Franz, Wolfgang, and Heinz König, 1986, The Nature and Causes of Unemployment in the Federal Republic of Germany since the 1970s: An Empirical Investigation, Economica 53, S219-S244.

Görzig, Bernd, Joachim Schintke, and Manfred Schmidt, 1995, Produktionsvolumen und - potential, Produktionsfaktoren des Bergbaus und des Verarbeitenden Gewerbes, Bundesrepublik Deutschland ohne Beitrittsgebiet, Statistische Kennziffern, 37. Folge, 1970-1994, DIW (Deutsches Institut für Wirtschaftsforschung), Berlin.

Gruber, Jonathan, 1994, The Incidence of Mandated Maternity Benefits, American Economic Review 84(3), 622-641.

Gruber, Jonathan, 1997, The Incidence of Payroll Taxation: Evidence from Chile, Journal of Labor Economics 15(3, pt.2), S72-S101.

Gruber, Jonathan, and Alan B. Krueger, 1991, The Incidence of Mandated Employer-Provided Insurance: Lessons from Workers' Compensation Insurance, in: David Bradford (ed.) Tax Policy and the Economy, vol. 5, MIT Press, Cambridge, Massachussetts.

Hamermesh, Daniel S., 1993, Labor Demand, Princeton University Press, Princeton, New Jersey.

Hamermesh, Daniel S. and Gerard A. Pfann, 1996, Adjustment Costs in Factor Demand, Journal of Economic Literature 34, 1264-1292.

Hansen, Gerd, 1996, Unemployment and the Wage Wedge in Germany - Simulations of a Small Cointegrated System, Zeitschrift für Wirtschafts- und Sozialwissenschaften 116, 167-183.

Hart, Robert A. and Peter G. McGregor, 1988, The Returns to Labour Services in West German Manufacturing Industry, European Economic Review 32, 947-963.

Hart, Robert A. and Seiichi Kawasaki, 1988, Payroll Taxes and Factor Demand, Research in Labor Economics 9, 257-285.

Huber, P. J., 1964, Robust Estimation of a Location Parameter, Annals of Mathematical Statistics 35, 73-101.

Keane, Michael P. and Eswar S. Prasad, 1996, The Employment and Wage Effects of Oil Price Changes: A Sectoral Analysis, Review of Economics and Statistics 78(3), 389-400.

König, Heinz, 1976, Neoklassische Investitionstheorie und Investorenverhalten in der Bundesrepublik Deutschland, Jahrbücher für Nationalökonomie und Statistik 190, 316-348. 
König, Heinz and Winfried Pohlmeier, 1988, Employment, Labour Utilization and Procyclical Labour Productivity, Kyklos 41(4), 551-572.

König, Heinz and Winfried Pohlmeier, 1989, Worksharing and Factor Prices: A Comparison of Three Flexible Functional Forms for Nonlinear Cost Schemes, Journal of Institutional and Theoretical Economics 145, 343-357.

Kraft, Kornelius, 1991, Lohnflexibilität und Beschäftigung in der bundesdeutschen Industrie, Jahrbücher für Nationalökonomik und Statistik 3, 239-253.

Kraft, Kornelius, 1997, Hiring and Dismissal Costs in Theory and Practice: A Comparison of Institutional Constraints and Employment Adjustment Patterns in Six OECD Countries, Kyklos 50(3), 341-368.

Machin, Stephen, and Alan Manning, 1997, Minimum Wages and Economic Outcomes in Europe, European Economic Review 41, 733-742.

Nadiri, M. Ishag, and Sherwin Rosen, 1969, Interrelated Factor Demand Functions, American Economic Review 59, 457-471.

Nakamura, Shinichiro, 1986, A Dynamic Multisector Model of Production, Investment and Prices Based on Flexible Cost Functions, DIW Vierteljahreshefte zur Wirtschaftsforschung 1/2, 110-122.

Nickell, Stephen J., 1986, Dynamic Models of Labour Demand, in: Ashenfelter, Orley and Richard Layard (eds.), Handbook of Labor Economics, Amsterdam, North Holland, 473-522.

OECD, 1994, The OECD Jobs Study Evidence and Explanations - Part II: The Adjustment Potential of the Labour Market, Paris.

OECD, 1995, Real Wage Resistance and Unemployment: Multivariate Analysis of Cointegrating Relations in 10 OECD Countries, The OECD Jobs Study - Working Papers Series No. 10, Paris.

Peeters, Jan, 1986, The "Machine Contribution" in the European Scene, Intereconomics 21/6, 288294.

Rhodes, Martin, 1996, Globalization and West European Welfare States: A Critical Review of Recent Debates, Journal of European Social Policy 6(4), 305-327.

Rossana, Robert J., 1990, Interrelated Demands for Buffer Stocks and Productive Inputs: Estimates for Two-Digit Manufacturing Industries, Review of Economics and Statistics 72(1), 19-29.

SVR (Sachverständigenrat zur Begutachtung der gesamtwirtschaftlichen Entwicklung), 1995, Im Standortwettbewerb - Jahresgutachten 1995/96, Metzler-Poeschel Stuttgart.

SVR (Sachverständigenrat zur Begutachtung der gesamtwirtschaftlichen Entwicklung), 1996, Reformen voranbringen - Jahresgutachten 1996/97, Metzler-Poeschel Stuttgart.

Schmidt, C.M., 1994, Relative Wage Effects of German Unions, CEPR Discussion Paper No. 918.

Smith, Owen E., 1994, The German Economy, New York.

Stark, E. and G. Jänsch, 1988, Faktoreinsatzverhalten im Verarbeitenden Gewerbe: Eine sektorale Analyse unter Verwendung eines Translog-Modells," DIW Viertelsjahreshefte zur Wirtschaftsforschung 1/2, 79-95.

Statistisches Bundesamt, various years, Fachserie 17 (Preise), Reihe 3 (Preisindex für den Wareneingang des Produzierenden Gewerbes).

Steiner, Viktor, 1996, Employment and Wage Effects of Social Security Financing - An Empirical Analysis of the West German Experience and Some Policy Simulations, ZEW Discussion Paper 96-14.

Summers, Lawrence H., 1989, Some Simple Economics of Mandated Benefits, American Economic Review 79(2), 177-183.

VDR (Verband Deutscher Rentenversicherungsträger), 1994, Rentenversicherung in Zahlen.

White, H., 1980, A Heteroscedasticity-Consistent Covariance Matrix Estimator and a Direct Test for Heteroscedasticity, Econometrica 48, 817-838. 


\section{Appendix}

1 .

Since 1982: Calculated as total costs of used energy per MWh, in prices of 1985.

Prior to 1982: Since data on the energy costs prior to 1982 is not available we calculated the industry-specific ratio of energy use out of overall material use as of 1982. This ratio in combination with information on costs of material was utilized to approximate energy prices.

Source: Statistical Yearbook of Germany, several issues and Statistisches Bundesamt, Fachserie 4, Reihe 4.1.1.

Capacity Utilization: Fraction of gross value added out of potential value added, in percent.

Output Level: Effective volume of gross value added, in DM billion and prices of 1985.

Source: Unless stated otherwise Görzig et al., 1995.

2.

Descriptive Statistics

\begin{tabular}{lcccc} 
Variable & Mean & $\begin{array}{c}\text { Standard } \\
\text { Deviation }\end{array}$ & Minimum & Maximum \\
\hline Contribution Rate & 0.165 & 0.09 & 0.16 & 0.20 \\
Employment & 220.110 & 256.08 & 14.00 & 1081.10 \\
Hours & 31.878 & 2.09 & 24.94 & 37.80 \\
Capital & 33.628 & 36.59 & 2.42 & 167.90 \\
Capacity Utilization & 84.173 & 6.18 & 49.30 & 97.30 \\
Energy & 5.125 & 8.09 & 0.19 & 45.34 \\
Predicted Wages & 30.280 & 10.27 & 12.40 & 70.41 \\
Predicted Interest Rates & 81.914 & 8.94 & 64.42 & 102.04 \\
Predicted Energy Price & 116.14 & 59.11 & 20.91 & 362.27 \\
Predicted Output & 16.092 & 18.91 & 1.22 & 81.46 \\
Predicted Export & 24.732 & 14.15 & 2.35 & 61.48 \\
\hline Obdina
\end{tabular}

Observations: 576. Time Period: 1977-194. Number of Industries: 32. 